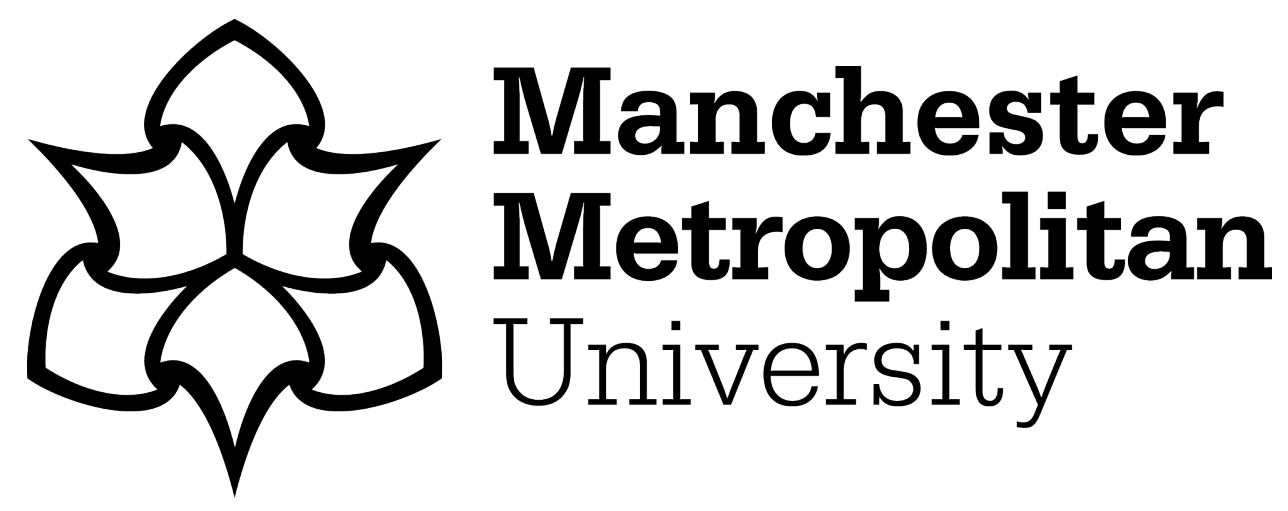

Leal Filho, W, Salvia, AL, Frankenberger, F, Akib, NAM, Sen, SK, Sivapalan, S, Novo-Corti, I, Venkatesan, M and Emblen-Perry, K (2021) Governance and sustainable development at higher education institutions. Environment, Development and Sustainability, 23 (4). pp. 6002-6020. ISSN 1387-585X

Downloaded from: https://e-space.mmu.ac.uk/626417/

Version: Accepted Version

Publisher: Springer

DOI: https://doi.org/10.1007/s10668-020-00859-y

Please cite the published version 


\title{
Governance and Sustainable Development at Higher Education Institutions
}

\author{
Leal Filho W, Salvia AL, Frankenberger F, Akib NAM, Sen SK, Sivapalan S, Novo-Corti I, \\ Venkatesan M, Emblen-Perry K
}

\author{
Environment, Development and Sustainability 01 Jan 2020 DOI \\ https://link.springer.com/article/10.1007/s10668-020-00859-y
}

\section{Introduction}

This section of the paper discusses the idea of governance and sustainable development at higher education institutions. The section first delves into the definition of the concept of governance as it relates to sustainable development at higher education institutions. Following this, a review of current global developments and limitations on governance and sustainability within the higher education sector is highlighted. The review ends with a call for the need for further research in the area, and the manner in which the present research is able to bridge this gap.

Universities and stakeholders within these institutions play a significant role in shaping the sustainable development agenda (Leal Filho 2012; Sivapalan 2016; Wals et al. 2016). International debates on sustainable development within the higher education sector can be traced back to as early as the 1990s, through initiatives such as the University Charter for Sustainable Development, the Kyoto Declaration on Sustainable Development and the Talloires Declaration (Jones, Selby and Sterling 2010). Other sustainable development focused initiatives that have made a governance mark within the sector include the Ubuntu Declaration, The Thessaloniki Declaration, the World Declaration, the Earth Charter and the Lüneburg Declaration (Byrne et al. 2010). However, it was the Decade of Education for Sustainable Development (2005-2014) and the Rio 2012 summit that firmly set the direction and space for the higher education sector to be formally involved in advocating for the need for institutions of higher learning to embody sustainable development within all aspects of its institutional operations.

Prior to understanding governance for sustainable development within the higher education context, the concept of sustainability governance shall briefly be discussed first. Sustainability governance, according to research conducted by Van Zeijl-Rozema, Cörvers, Kemp and Martens (2008), involves two key perspectives from sustainable development, and two principle models of governance. While ecology and well-being form the sustainability dimensions, hierarchical and deliberate means embody the modes of governance. The intersections of these sustainability perspectives and models of governance make way for four types of governance for sustainable development, namely ecological-hierarchical, ecologicaldeliberative, well-being-hierarchical and well-being deliberative. These findings are significant, as it provides a strategic framework for deliberations on sustainability governance structures, including that of higher education institutions (Tappeser and Mayer 2012).

Interestingly though, while higher education governance has been an area of study keenly investigated by many researchers, there does not seem to be a common definition to 
describe the term. An instance is exemplified here, using the definition of The Code of Governance of Irish Universities 2012, where governance in higher education is referred to as 'the systems and procedures under which organisations are directed and controlled. A robust system of governance is vital in order to enable organisations to operate effectively and to discharge their responsibilities as regards transparency and accountability to those they serve' (Code of Governance of Irish Universities 2012). Within the context of sustainable development at higher education institutions, the term governance has come to be defined as 'overall, institution-wide aims or policy, versus those specific to a particular unit or topical focus' (Vaughter 2016, p. 25). Discussions on governance often include the institution's predominant aims and purposes, accountability, finance, long-term planning and leadership, note Vaughter et al. (2016).

It is apparent from the literature that globally, studies on the notion of governance and sustainable development within the higher education sector remain scarce. Our observations are supported by findings from Baker-Shelley et al. (2017), Mader et al. (2013) and Spira et al. (2013). There is thus a need to address these limitations, to enable greater impact for the proliferation of sustainability governance within higher education institutions.

\section{Advantages of sustainability governance to higher education institutions}

Sustainability encased governance in higher education is a new social contract with society and environment (Gibbons 1999). Institutions of higher learning draw advantages through a transactional view of education that builds social entrepreneurship (Dacin et al. 2011). Governance-enabled and sustainability-empowered higher education can benefit as social audit that usher creative enquiry encased in ethics (Johnson et al. 2016). Another advantage is the creation of learner-eco-systems that network and disseminate need for governance and adds adaptivity (Crow 2010a). Governance enables heterogeneity and adds the role of scale in sustainability education to combat sustainability challenges with respect to climate unpredictability, air deterioration, water insecurity and overuse of natural resources. The advantages are summarized in Table 1.

\begin{tabular}{llll}
\hline $\begin{array}{l}\text { Higher education } \\
\text { dilemma }\end{array}$ & $\begin{array}{l}\text { Contribution through } \\
\text { Sustainability practices }\end{array}$ & $\begin{array}{l}\text { Benefits derived } \\
\text { from Governance }\end{array}$ & Next steps \\
\hline $\begin{array}{l}\text { Quantum of sensitivity } \\
\text { to societal, } \\
\text { environmental and } \\
\text { economic } \\
\text { repercussions }\end{array}$ & $\begin{array}{l}\text { New Social contract with } \\
\text { society \& environment } \\
\text { (Gibbons 1999); } \\
\text { policymakers, corporate / } \\
\text { services and people }\end{array}$ & $\begin{array}{l}\text { Learner eco- } \\
\text { systems that gets } \\
\text { disseminated (Crow }\end{array}$ & $\begin{array}{l}\text { Has seminal effect, } \\
\text { lays foundations for } \\
\text { governance-enabled } \\
\text { and sustainability- } \\
\text { empowered higher } \\
\text { education }\end{array}$ \\
\hline $\begin{array}{l}\text { Trusteeship, } \\
\text { heterogeneity with } \\
\text { local, regional, global } \\
\text { challenges (Crow }\end{array}$ & $\begin{array}{l}\text { Sustainability- } \\
\text { empowerment, community } \\
\text { outreach to environment } \\
\text { inclusive habitats (Keddy } \\
\text { 1991) }\end{array}$ & $\begin{array}{l}\text { Governance enable } \\
\text { heterogeneity on } \\
\text { outlook (Nordqvist } \\
\text { et al. 2014) }\end{array}$ & $\begin{array}{l}\text { Societal fabric is } \\
\text { interspersed in the } \\
\text { curriculum that needs } \\
\text { to be governance- } \\
\text { enabled (Deemer and }\end{array}$ \\
\hline
\end{tabular}




\begin{tabular}{llll}
\hline $\begin{array}{l}\text { Governance-ingrained } \\
\text { finance for sustainable } \\
\text { education could } \\
\text { restructure brick and } \\
\text { mortar with online } \\
\text { virtual education (Leer } \\
\text { and Ivanov 2013) }\end{array}$ & $\begin{array}{l}\text { Systemic social } \\
\text { transformation (Cobián and } \\
\text { Reátegui 2009). }\end{array}$ & $\begin{array}{l}\text { Role models } \\
\text { incorporate } \\
\text { governance } \\
\text { attributes }\end{array}$ & $\begin{array}{l}\text { Connectivity among } \\
\text { financing and } \\
\text { governance in } \\
\text { education services } \\
\text { (Klugman 1999) }\end{array}$ \\
\hline $\begin{array}{l}\text { Massively multi-user } \\
\text { online graphical } \\
\text { environments (Yee }\end{array}$ & $\begin{array}{l}\text { Virtual teams can group-in } \\
\text { policy-makers, processors } \\
\text { and community as virtual } \\
\text { teams. Social networking } \\
\text { environments can spread } \\
\text { across geographical habitats } \\
\text { (Christensen et al. 2007). }\end{array}$ & $\begin{array}{l}\text { Anthropocene } \\
\text { (Biermann et al. }\end{array}$ & $\begin{array}{l}\text { 2012) } \\
\text { preparedness } \\
\text { (Connolly et al. }\end{array}$ \\
\hline
\end{tabular}

Table 1 - Advantages of sustainability governance to higher education institutions

A previous study on sustainable development policies as pre-conditions for sustainability efforts at universities (Leal Filho et al. 2018) has shown that albeit important, such policies are not essential for a successful engagement on sustainability efforts.

\section{Some trends on governance on sustainable development at higher education institutions}

The extent of the use of the term "Governance" is relatively new, but its essence is ageold. One of the first stages of the use of the governance concept is in the 1990s, linked to the international aid and donors, particularly to the International Monetary Fund (IMF), the World Bank and the United States of America (USA) (Nanda 2006). In this context, the concept initially focuses on economic issues. As the goal is that aid achieves success, nevertheless this concept goes beyond a single issue or institution, in this work, the specific target is the governance in the framework of HEIs. Good management is an initial step for good governance, but the close relationship between economics and politics immediately reveals the importance of the interdependence between economic governance (more linked to economic management) and political governance (more related to confidence in markets), which should be considered as a whole. Lewis T. Preston, a former World Bank President, highlighted the importance of good governance as an essential complement to economic policies. This is due to the fact that the markets' efficiency is strongly related to a predictable and transparent policy framework in the public sector, and all of this is necessary for economic development (World Bank 1992). Later, it was underlined by Stiglitz (1999) that from the point of view of the economics of the public sector, market failures are as important as the way we address them. Whilst IMF, as well as World Bank, initially focused on economic issues, the US identified nine principles; including economic growth, democracy, governance, and social transition. Among them was also the sustainability for achieving development (U.S. AID 2005). The European Union states that "'European governance' designates the body of rules, procedures and practices that relate to the way powers are exercised in the EU", with the aim of strengthening democracy and bringing citizens closer to the European institutions (European Union 2018). The concept of 
governance is related to democracy, participation and sustainable development in all institutions and in HEIs in particular.

The HEIs concern on with long-term sustainability deals with projects, policies, certifications, and staff dedicated to this commitment. There are different ways of implementing sustainability at higher education institutions (Leal Filho 2010), and the work of Smith (1993) was one of the pioneers of this endeavour. Recently, Bauer et al. (2018) focused on the five dimensions of politics, profession, organisation, knowledge, and visibility and underlined the lack of a holistic approach, which is also claimed by Lozano (2018). Some works have contributed to this debate, such as Drahein et al. (2019), who presented eight models applied in a HEI context. There are different groups of change agents which are responsible for the advancement of the necessary changes, and that those changes into organizations structure should be analysed taking into account the interaction of the agents, organizational structure and culture (Spira et al. 2013). Despite the differences among HEIs structures and cultures, they face similar challenges related to sustainability governance (Soini et al. 2018). There is a strong relation between sustainability commitment and implementation, and signing of declarations, charters, and initiatives (DCIs) (Lozano et al. 2015).

Drahein et al. (2019) studied 170 HEI directives and concluded that there is a consensus on the difficulty of the academic community's perception on the importance of developing a sustainability model for managing HEI institutions. They underline the importance of the adoption of sustainable practices and auditing them. Agents interaction, organization, and culture of the institution, as well as the help coming from tools, certifications, and legislation, among others, are important items needed to justify a sustainability agenda towards local decision makers (Spira et al. 2013).

One of the outcomes of the assessment process is boosting the learning process to improve and change institutions (Disterheft et al. 2016). Evaluating achievements on sustainability is not easy as there is not a unique measurement or instrument for evaluating results (Popescu and Beleau 2014). Several specific tools and mechanisms where applied in several universities which ranked the various institutions (Disterheft et al. 2016). These systems include Quality Management Systems (ISO 9001), related to environmental issues Environmental Management Systems (EMS) were used, or in the field of Social Responsibility, the Social Responsibility Standards (SA8000 and ISO 26000) (Aleixo et al. 2018). The certification is not widely implemented in HEIs yet, as Aleixo et al. (2018) has proven; for example, over $60 \%$ of Portuguese HEIs have not gotten at least one certification. To generate a balanced report, which includes the environmental, economic and social performance, the Global Reporting Initiative (GRI) gives a number of essential reporting principles (FerreroFerrero et al. 2018). As these principles are independent with differing focuses, a holistic approach for sustainability at HEIs is needed (Lozano 2018).

The commonly accepted main issues related to governance point to the management of public resources as well as social and political issues (Kjaer 2011). Since sustainable development is based on the "triple bottom line" (economic, environmental and social) (WCED, 1987), the narrow relation between them relies on their own nature. The complexity of the "governance" term, as well as semantic differences worldwide, come together with the multiplicity of factors involved in it. Something similar occurs with the related concept of Sustainability Reporting (Fonseca et al. 2011). Nevertheless, there is a common agreement about the intrinsic content of both concepts, which is determined by good management and wide and fair participation, in the framework of the so-called "three pillars of sustainability". 
The governance in the context of the HEIs becomes a key issue since they can be seen as a subsystem in society called to play an important role in transforming their surrounding communities and society (Baker-Shelley et al. 2017). The deep social imbrication that universities must have with their surrounding reality and the need to adequately serve that society, may lead to thinking about governance formulas adapted to the socio-economic and environmental environment in which they find themselves.

The engagement of HEIs with environmental issues has been widely recognized. In 1972, the Stockholm Declaration on the Human Environment already stated the importance of education for environment preservation. This concern remains and increased due to the United Nations Higher Education Sustainability Initiative (UN HESI) created in 2012 in the run-up to the United Nations Conference on Sustainable Development (Rio+20) with the engagement of over 300 universities worldwide (United Nations, 2019). Another example of success is the Higher Education and Research for Sustainable Development (HESD) platform, partnered by the United Nations Educational, Scientific and Cultural Organization (UNESCO), among others, with the aim of becoming a global reference portal and for giving visibility and connection to actors and institutions in order to foster awareness and cooperation.

But the HEIs' engagement with sustainability goes beyond environmental issues. In fact, besides the commitment with economic issues being particularly remarkable, the interest and influence of HEIs as an innovative motor (both technical and social) is widened to the sustainability issues (United Nations 1972) and it is recognized by society. Whereby HEIs socio-economic engagement is considered as its distinguishing purpose alongside teaching and researching (Vorley and Nelles 2009). Therefore, particular aspects such as good performance, management and decision-making become crucial. The social engagement of HEIs is in particular need of stronger analysis, in line with the "third mission" of universities (Trencher et al. 2014). This is due to the complexity of the two main dimensions (the internal -with members of the HEIs- and external -with society-) which are involved in most of the social issues of societies and goes beyond the internal management of the institutions. Participation is one of the pillars of good governance and Ceulemans et al. (2015) and Disterheft et al. (2015) have shown the importance of fostering participation for Higher Education for Sustainable Development (HESD), particularly from an institutional level.

The assessment of the achievements, by means of some specific index is important in order to evaluate the advancements on Sustainable Development (SD) at HEIs. In this sense, sustainability report diffusion allows HEIs to know how and where improvements are taking place and see the role which they play in both the academic and society spheres (Drahein et al. 2019). Some universities produce sustainability reports in different manners, some of them more than once a year (Spira et al. 2013). Nevertheless, academic literature has evidenced the low number (Alonso-Almeida et al. 2015; Ceulemans et al. 2015; Fonseca et al. 2011), quality (Fonseca et al. 2011; Lozano 2011) and consistency in reports (Alonso-Almeida et al. 2015). For example, less than half of Portuguese Universities implemented or produced sustainability reports, although they considered them relevant (Aleixo et al. 2018). Various sustainability models arose from the (GRI) (Global Reporting Initiative 2013), as summarized by Lozano (2006). Some limitations were shown in the GRI adaptation to HEIs (Fonseca et al. 2011), particularly as it excludes some valuable indicators. In addition to the GRI, other sustainability assessment tools to be considered are the STARS (Sustainability Tracking, Assessment and Rating System), the AA1000 (Institute of Social and Ethical Accountability Standard), the EMAS (Eco-Management and Audit Scheme), the ISO 14001 (International 
Organisations for Standardisation) and the SA8000 (Council on Economic Priorities Accreditation Agency Social Accountability Standard), among others.

In order to improve the SD in HEIs, having a specific budget is key. However, this is generally a weakness in a large number of institutions (Leal Filho et al. 2018). The lack of financial support is one of the obstacles to the implementation of a program or action plan as well as the limited human resources needed to boost these plans. This is due in part to the fact that the workers in charge of these issues (related to sustainability) are frequently involved in other tasks (Leal Filho et al. 2018). Aleixo et al. (2018) analysed the disposal of a specific budget for practices promoting SD among the Portuguese HEIs and found that it was the least implemented economic practice.

Governance, as a key for sustainability, is highlighted by Jones (2016) from the point of view of sustainable business models; pointing it out as one of the five mainstays for sustainability. In the holistic definition of more sustainable business models (MSBMs) provided by Lozano (2018), governance is a part of system elements, that is one of the companies' resources, which contribute to sustainability, and this issue is also extended to HEIs (BakerShelley et al. 2017). In the higher education setting, governance presents additional complexity to the concept itself. This added complexity lies in the dichotomy of higher education institutions, whose scope encompasses both teaching and research, together with the transfer of knowledge and social commitment. The complexity of the governance in HEIs is directly related to the characteristics of the framework in which their activity is carried out. The management and promotion of the participation of internal and external (social) agents is part of a very versatile world with very different profiles, ranging from the pure sciences to the humanities, through the social, technological or economic and law sciences (Soini et al. 2018). The Universities' staff are key point for promoting SD. The management and staff support are integral to the implementation of environmental management systems and sustainability. Lack of this support could become a barrier, which is why the commitment from senior and middle management staff on the implementation of sustainability initiatives it should be taken into account (Aleixo et al. 2018; Ceulemans et al. 2015) as well as the perceived support of superiors into the organizational structure in order to boost staff commitment (Baker-Shelley et al. 2017). On the other hand, key positions occasionally held down for many years by a single occupant, and in the case of the necessity of his or her replacement, it would most likely take the new staff many years to join the culture of sustainability (Leal Filho et al., 2018). To integrate sustainability issues into universities the expectation of academic and non-academic staff may differ, as well as those of the students (Ferrero-Ferrero et al. 2018; Ceuleman 2015). Their involvement on the HEI sustainability performance assessment process is greatly reliant on their own perceptions and practices and this influences the organization's performance. However, it has been found that employees tend not to be very knowledgeable on basic sustainability concepts, and are uncertain on what their practical mission in the whole mechanism for a sustainability performance assessment is (Coutinho et al. 2018).

There is a lack of adequate personnel training to tackle matters related to sustainable development, which is for university staff to make them feel confident about the concepts of sustainability, and in turn include them as part of their day-to-day work (Leal Filho 2010). Due to the lack of knowledge among the staff, the necessity of education and training on sustainability issues has been underlined in the context of HEI, and that it would be better to do it before their engagement on the performance assessment (Coutinho et al. 2018). In this context, the implementation of a "sustainability codex" for new employees was suggested by 
some experts (Bauer et al. 2018). Disterheft et al. (2016) highlighted the importance of training of staff, which has been proved by Leal et al. (2018) for Brazilian Universities.

There is a growing demand for HEIs to play an active role in providing help in responding to society's concerns, in which sustainability represents a particularly relevant issue (Soini et al. 2018). HEIs are knowledge-producer institutions, which positions them as engines of economic growth (Trencher et al. 2014) and, as a consequence, of sustainable development. Additionally, their role as technology transfers to society, as well as education centres, put them in the core of essentials of Sustainable Development Goals (SDGs) and in boosting sustainability. All these aspects must be included to achieve good governance in the HEIs.

Given this, there is increasing research on the field of applied analysis (Gamage and Sciulli 2017; Ramos et al. 2015; Rath and Schmitt 2017). Still, much more research is needed to obtain stronger results that lead to the provision of a general sustainable framework.

HEIs play a key function as benchmarks for sustainability research, education, and cooperation in sustainability transform. Simultaneously, their governance is facing a complex and changing situation, where further analysis is needed (Baker-Shelley et al. 2017; Soini et al. 2018), particularly on the importance of evaluating the impact of universities on sustainability. This has already been approached in a quite fragmented way in the HESD field (Ceulemans et al. 2015), and its assessment could give some clues for specific ways to foster good governance on HEIs. Findler et al. (2019) has analysed sustainability assessment in higher education and showed that more research and advances are needed. At the same time, they emphasised the importance given to the governance issues in all analysed indicators.

\section{Methodology}

In order to collect experiences from a sample of universities in the context of governance and sustainability, an international survey was developed. The following steps summarise the process undertaken:

a) The survey instrument was developed by the authors following not only items covered by the literature (such as sustainability plans, certification and reporting) but also an investigation concerning the main challenges for integrating governance and sustainable development. It was pre-tested in the authors' universities in order to check for redundancies and ensure the quality of the instrument. A summary of the survey is presented in Table 2. In the end, an open space for comments or highlights was also provided.

\begin{tabular}{ll}
\hline Question/topic & Possible Responses \\
\hline $\begin{array}{l}\text { One common governance instrument is a } \\
\text { sustainable development policy, programme } \\
\text { or action plan. In this context, please tick one } \\
\text { of the relevant boxes: }\end{array}$ & $\begin{array}{l}\text {-My university already has a sustainable development policy, programme } \\
\text { or action plan; -My university does not yet have a sustainable development } \\
\text { policy, programme or action plan, but plans to produce one; -My university } \\
\text { does not yet have a sustainable development policy, programme or action } \\
\text { plan, and does not plan to produce one. }\end{array}$ \\
\hline $\begin{array}{l}\text { How are matters related to sustainable } \\
\text { development addressed at your university? }\end{array}$ & $\begin{array}{l}\text {-Under the coordination of the Rector or Vice-Chancellor/Principal; - } \\
\text { Under the coordination of one of the Pro-Vice-Chancellors or Vice- } \\
\text { Rectors; -Under the coordination of a sustainability office or green office; } \\
\text {-Decentralised at the Faculties level; -There is no formal sustainable } \\
\text { development structure at our university; -Other }\end{array}$ \\
\hline
\end{tabular}




\begin{tabular}{|c|c|}
\hline $\begin{array}{l}\text { Is your university certified by one of the } \\
\text { common mechanisms (e.g. ISO/EMAS)? }\end{array}$ & Yes; No \\
\hline $\begin{array}{l}\text { If the answer is yes, which one (multiple } \\
\text { choices possible): }\end{array}$ & $\begin{array}{l}\text {-ISO 9000; -ISO 14001; -EMAS (Europe); STARS (North America); } \\
\text { Other }\end{array}$ \\
\hline $\begin{array}{l}\text { Is there a budget from the central } \\
\text { administration to support efforts related to } \\
\text { sustainable development? }\end{array}$ & Yes; No \\
\hline $\begin{array}{l}\text { Does the university produce regular (e.g. } \\
\text { yearly, bi-yearly) sustainability reports? }\end{array}$ & Yes; No \\
\hline $\begin{array}{l}\text { Are there members of staff (e.g. a } \\
\text { sustainability coordinator) specifically to } \\
\text { support efforts related to sustainable } \\
\text { development? }\end{array}$ & Yes; No \\
\hline $\begin{array}{l}\text { Are there specific training programmes or } \\
\text { opportunities related to sustainable } \\
\text { development? If so, which options are offered? }\end{array}$ & Yes; No \\
\hline $\begin{array}{l}\text { Which elements pose a challenge to the efforts } \\
\text { of integrating governance and sustainable } \\
\text { development? (multiple choices possible) }\end{array}$ & $\begin{array}{l}\text { Lack of expertise; Lack of interest from staff; Lack of funding; Lack of } \\
\text { materials/resources; Lack of support from administration; Other }\end{array}$ \\
\hline
\end{tabular}

Table 2 - Summary of the survey instrument to collect experiences on governance and sustainability at HEIs

b) After the pre-test, the online survey was shared using the application Google Forms. All members of the Inter-University Sustainable Development Research Programme (IUSDRP, https://www.haw-hamburg.de/en/ftz-nk/programmes/iusdrp.html) received the invitation to participate in the survey. This international programme has currently more than 120 universities as members and covers all continents.

The survey remained open for one month (March/2019) and received 46 responses from different universities. The sample is divided into $41 \%$ universities from Latin and North America, 35\% from Europe, 13\% from Africa, and 11\% from Asia-Pacific.

c) The final step is the presentation of results through descriptive analysis. The results of each question/topic from the survey was presented and discussed in relation to the literature review. With support of the software SPSS, potential correlations between the existence of a governance instrument (sustainable development policy, programme or action plan) and the existence of certification, budget, report, staff and training was also assessed. For that, the Spearman correlation test was used (for non-normal distributions, as verified by the Shapiro-Wilks test).

The additional space for comments at the end of the survey also provided interesting topics that were brought to the discussions.

\section{Results and discussions}

This section presents the descriptive analysis and discussions from the survey results. The following topics are presented: sustainable development policy, certification, organisational structure, budget, reports, team for sustainability, staff training, and challenges for the integration of sustainability and governance. 
When it came to having a sustainable development policy as a governance instrument, $63 \%$ of the respondents answered that their university already has a sustainable development policy, programme or action plan; $20 \%$ answered that the university does not have it, but plans to produce one; and $17 \%$ answered that the university does not have one and does not plan to produce one. The majority of universities $(65 \%)$ do not have a certification, while the rest of the responses $(35 \%)$ do have certifications from one or multiple certification bodies $(25 \%$ responded yes for having more than one certification). Some of the certifications are region oriented, for example, EMAS (Eco-Management and Audit Scheme, for countries under EU, awarded to organisations that continuously improve their environmental performance), and STAR (Community Rating System, which evaluates local sustainability mainly in North America). The majority of universities with certifications received it through ISO. Table 3 shows the list of certifications on sustainable development awarded to the universities.

\begin{tabular}{ll}
\hline Certification & $\mathbf{\%}(\mathbf{N}=\mathbf{1 6})$ \\
\hline ISO 9000 & $44 \%$ \\
\hline STARS & $37 \%$ \\
\hline ISO 14001 & $19 \%$ \\
\hline EMAS & $13 \%$ \\
\hline ISO 50001 & $6 \%$ \\
\hline PRME & $6 \%$ \\
\hline
\end{tabular}

*the percentage is more than $100 \%$ as some university responded receiving more than one certification Table 3 - List of certifications on sustainable development awarded to universities*

Both sustainable policy and certification relates to long-term sustainability. Developing a policy for sustainability demands involvement of several stakeholders at the university, requiring the commitment of a certain group of managers. As far as certification is concerned, the first challenge is to involve all departments, schools, centres, and other structures, so the certification requirements can be implemented at the university. All these actions take time, and produce long-term benefits for the university. In this way, when $63 \%$ of respondents indicates that the university has a policy in practice, but only $34 \%(16 / 46)$ have certifications implemented, it means the university is looking into the future. However, there is still room to implement further long-term activities', as certifications boost the learning process and improve and change institutions, as indicated by Disterheft et al. (2016).

The organisational structure of the university plays an important role in matters related to sustainable development. When a university does not organize itself to undertake actions towards $\mathrm{SD}$, the institution is considered to be in the early stages of sustainability; meaning that there is no formal sustainable development structure in place. A university could arrange itself in order to address sustainability by producing a coordination office or a green office. The coordination might be under the structure of pro-vice-chancellor or vice-rectors, the rector, vice-chancellor or principal, or decentralized at the faculty's levels. Other organizational structures are also possible.

Related to this issue, $30 \%$ of the sample responded that their universities have a sustainability office or green office responsible in coordinating matters of on sustainability (Table 4). About $22 \%$ of universities do not have a formal sustainable development structure. Whilst the remainder, where there is no sustainability office or green office, about $30 \%$ (15\%; $15 \%)$ are under the coordination of their pro-Vice Chancellor/Vice Rector or Rector/Vice Chancellor/Principal. Lower percentages of universities addressed the matter of sustainable development through Student's office and sustainable committee. 


\begin{tabular}{ll}
\hline Responses & $\mathbf{\%}(\mathbf{N}=\mathbf{4 6})$ \\
\hline Under the coordination of a sustainability office or green office & $30 \%$ \\
\hline There is no formal sustainable development structure at our university & $22 \%$ \\
\hline Under the coordination of one of the Pro-Vice-Chancellors or Vice-Rectors & $15 \%$ \\
\hline Decentralised at the Faculties level & $15 \%$ \\
\hline Under the coordination of the Rector or Vice-Chancellor/Principal & $13 \%$ \\
\hline Student Office of Sustainability & $2 \%$ \\
\hline Sustainable committee & $2 \%$ \\
\hline
\end{tabular}

Table 4 - Mechanism of sustainable development related matters addressed at university

The largest proportion of the sample (78\%) has some kind of organization, showing they are interested in addressing sustainability in a structured manner. However, $22 \%$ of universities have no formal sustainable development structure, even though the respondents are members of the IUSDRP. This indicates that universities still have scope to be more involved in sustainability, but it may also represent a barrier. As indicated by Baker-Shelley et al. (2017), the perceived support of superiors into the organizational structure boost the staff commitment, which is why the commitment from senior and middle management staff on the implementation of sustainability initiatives should be taken into account (Aleixo et al. 2018; Ceulemans et al. 2015).

Engagement is a necessary step towards sustainability and the following topics were questioned: available budget for sustainable development efforts, use of sustainability reports, staff members dedicated to sustainable development efforts, training programmes or opportunities related to sustainable development. Results are presented in Figure 1.

With these results, it can be inferred that all engagement areas have room for improvement. Even though the lack of budget is generally a weakness in a large number of institutions (Leal Filho et al. 2018), by increasing the central budget in some other areas - such as reporting and increasing the number of staff to support sustainability efforts - could be consequently improved. In terms of reporting, some authors indicate that by report diffusion, the HEI would know how and where to improve, which could improve their position in terms of the academy and society (Drahein et al. 2019). The offer of specific training programmes or opportunities related to sustainable development is in line with the suggestion of Disterheft et al. (2016). In order to address issues of low staff training the implementation of a "sustainability codex" for new employees, as suggested by some experts, could be introduced (Bauer et al. 2018).

The programmes or opportunities indicated by the respondents are mainly courses offered by the university. Besides that, universities apply other actions to promote sustainable development, as shown in Figure 2.

There are many challenges to governance integration and sustainable development. Such as, a lack of funding, lack of support from administration, lack of expertise, lack of interest from staff and lack of materials/resources. In Table 5, a summary of challenges to the efforts of integrating governance and sustainable development is presented. The percentage is more than $100 \%$ as this question accepted multiple answers. 


\begin{tabular}{ll}
\hline Lack of funding & $72 \%$ \\
\hline Lack of support from administration & $61 \%$ \\
\hline Lack of expertise & $50 \%$ \\
\hline Lack of interest from staff & $50 \%$ \\
\hline Lack of materials/resources & $48 \%$ \\
\hline
\end{tabular}

Table 5 - Challenges to the efforts of integrating governance and sustainable development

Besides these factors, in an open question the respondents indicated other challenges, such as willingness to contribute, lack of time, lack of political support, and not recognizing the Sustainable Development Goals as a way out. The two biggest challenges - lack of funding and lack of support from administration - indicate a need for more engagement from the universities' higher organizational structure.

These results are in line with Aleixo et al. (2018), Ceulemans et al. (2015) and Leal Filho (2010) regarding lack of support from administration; and with Coutinho et al. (2018) regarding lack of interest from staff which could be generated by low staff knowledge and training on issues related to sustainability.

In order to verify the correlation between the existence of governance instruments and the use of certification, dedicated budget and staff, sustainability report, and training opportunities, the Spearman correlation test was used. The results, as indicated in Table 6, show that having a governance instrument (such as a sustainable development policy, programme or action plan) is directly connected to having dedicated budget and staff for sustainability as well as the use of sustainability reporting. This reveals the positive impact of having governance instruments on other important sustainability issues of HEIs. The highest values of correlation were observed in the relation between dedicated budget and development of sustainability reporting, and dedicated staff for sustainability efforts and reporting.

\begin{tabular}{|c|c|c|c|c|c|c|c|}
\hline & & $\begin{array}{l}\text { Governance } \\
\text { Instrument }\end{array}$ & Certification & Budget & Report & Staff & Training \\
\hline \multirow{2}{*}{$\begin{array}{l}\text { Governance } \\
\text { Instrument }\end{array}$} & $\begin{array}{l}\text { Correlation } \\
\text { Coefficient }\end{array}$ & 1 & & & & & \\
\hline & Sig. (2-tailed) & & & & & & \\
\hline \multirow{2}{*}{ Certification } & $\begin{array}{l}\text { Correlation } \\
\text { Coefficient }\end{array}$ & 0.081 & 1 & & & & \\
\hline & Sig. (2-tailed) & 0.593 & . & & & & \\
\hline \multirow{2}{*}{ Budget } & $\begin{array}{l}\text { Correlation } \\
\text { Coefficient }\end{array}$ & $.393^{* *}$ & $.350^{*}$ & 1 & & & \\
\hline & Sig. (2-tailed) & 0.007 & 0.017 & . & & & \\
\hline \multirow{2}{*}{ Report } & $\begin{array}{l}\text { Correlation } \\
\text { Coefficient }\end{array}$ & $.471^{* *}$ & $.437^{* *}$ & $.703^{* *}$ & 1 & & \\
\hline & Sig. (2-tailed) & 0.001 & 0.002 & 0 & . & & \\
\hline Staff & $\begin{array}{l}\text { Correlation } \\
\text { Coefficient }\end{array}$ & $.509^{* *}$ & $.384^{* *}$ & $.580^{* *}$ & $.669^{* *}$ & & 1 \\
\hline
\end{tabular}




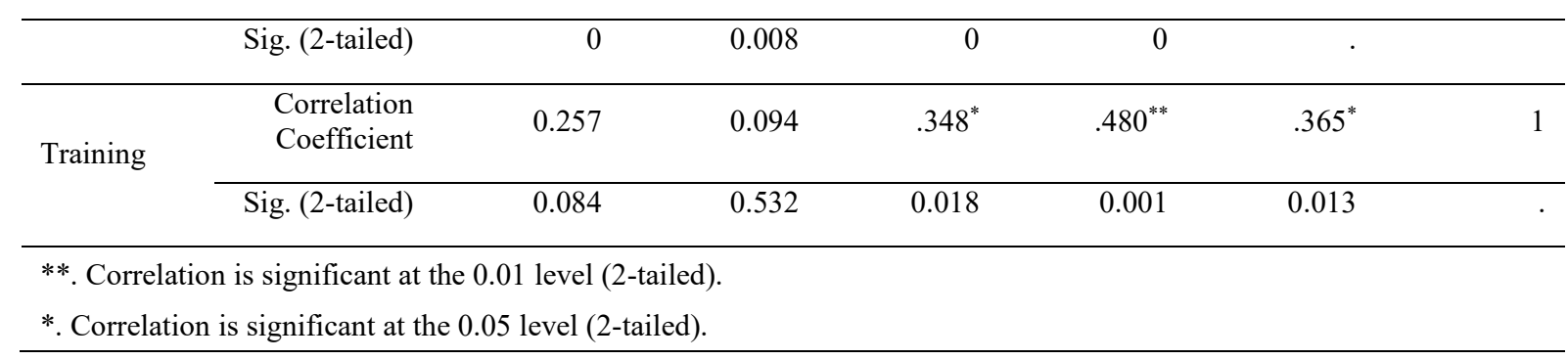

Table 6 - Correlations between governance and sustainability issues in HEIs

Based on the correlation analysis, it is also possible to identify the variables with most correlations. Report correlates to all variables, indicating that by developing a sustainability report, all other topics can be influenced (5/5). The second variable that most correlates to the others is staff $(4 / 5)$, indicating that having staff dedicated to issues related to sustainability can also influence SD. Budget correlates with some of the variables (3/5); certification only correlates with two variables; and training correlates only with one variable (reporting). Figure 3 presents the relevance of the studied variables.

Finally, some additional comments sent by the respondents provided interesting topics. It showed different levels of commitment/impact for SD. For example, one respondent indicated that the university is at the lowest level of adopting sustainable patterns. Another respondent also indicated that the university still does not address sustainability, but that a professor started recently a 'Sustainability Club', which triggered some actions at the universities highest structure levels.

Regarding an active role in the university, one respondent indicated that their university is a signatory of the Talloires Agreement, while in other university STARS was recently introduced and was trailing Green Impact for over a year. Concerning certifications, one respondent stated that the focus had been more on EMAS, and not strictly on SD. This is in line with Lozano et al. (2015), as there is a strong correlation between sustainability commitment and implementation, and signing of declarations, charters, and initiatives (DCIs).

In terms of university involvement to SD, one respondent answered that SD should start at the bottom with courses and certifications, otherwise the HEI will not engage on sustainability. Another respondent added that the way sustainability is treated in the university depends on which field is the dominant one at the HEI. They also indicated that campus service providers are key to succeeding in the implementation of SD.

In terms of criticisms, one respondent addressed the need to explore ecology as a science in a deep way, otherwise only common science will come out. Another respondent indicated that this research "seems to assume that sustainable development or ESD are a 'good thing"". The objective of this research was not to discuss SD or ESD as positive or negative, but to identify how governance and SD are related at university level.

The implications of the study are threefold. Firstly, it sheds more light on the subject matter of governance and sustainable development at higher education institutions, outlining some of the items which influence it. Secondly the review of current global developments and limitations on governance and sustainability within the higher education sector shows that whereas governance is regarded as important, there are some challenges which are being observed and which need to be addressed to as to provide a basis for long-term developments. 
These include lack of funding, lack of support from administration, lack of expertise, lack of interest from staff and lack of materials/resources, problems which, if not addressed, may compromise the ability of higher education institutions integrate governance and sustainable development.

Finally, the findings from study suggest that higher education institutions which have plans to implement a sustainable development policy as a governance instrument, are more likely to engage academic and service staff on sustainability efforts, than those who do not.

\section{Conclusions}

This paper has outlined the various means via which governance are seen as influencing the ways higher education institutions handle matters related to sustainable development. The study has one limitation in the sense that the sample, entailed responses from 46 different universities. However, since it encompassed universities from Latin and North America, Europe, Africa, and the Asia-Pacific region, it offers a rough profile of the trends currently seen. The assessments of an analysis of sustainable development policies, certification, organisational structure, budget, reports, team for sustainability, staff training, and challenges for the integration of sustainability and governance has shown that some disparities exist. For instance, many higher education institutions do not have any plans to implement a sustainable development policy as a governance instrument, and do not plan to produce one. In addition, many universities do not have any kind of certification, which may demonstrate the institutional commitment (or lack thereof) to sustainability. In addition to this, organisational structures cannot be regarded as fully satisfactory; there are many constraints related to budgetary provisions, reporting or staff training. The latter element is very important, as it provides a sound basis upon which academic and service staff may engage on sustainability efforts.

Overall, evidence from this study suggests that even though there are different opinions and attitudes on the role of governance, and the need for formal documents and commitments, it can still be regarded as an important component in supporting efforts of higher education institutions to include considerations on sustainable development as part of their strategies.

Governance instruments (such as sustainable development policies, programmes or action plans), especially when associated with a dedicated budget, staff for sustainability, and the use of sustainability reporting, leads to positive impacts on the ways sustainability issues are seen and implemented at higher education institutions.

As to future prospects, this paper has provided some useful insights into the complexities of governance as a factor influencing the institutional emphasis given to sustainable development. It is suggested that further studies be performed, to shed further light on how rules and standards may govern the conduct of people within each organisation.

\section{References}

Aleixo, A. M., Azeiteiro, U., \& Leal, S. (2018). The implementation of sustainability practices in Portuguese higher education institutions. International Journal of Sustainability in Higher Education, 19(1), 146-178. 
Alonso-Almeida, M. der Mar, Marimon, F., Casani, F., \& Rodriguez-Pomeda, J. (2015). Diffusion of sustainability reporting in universities: current situation and future perspectives. Journal of Cleaner Production, 106, 144-154.

Baker-Shelley, A., van Zeijl-Rozema, A., \& Martens, P. (2017). A conceptual synthesis of organisational transformation: How to diagnose, and navigate, pathways for sustainability at universities? Journal of Cleaner Production, 145, 262-276.

Bauer, M., Bormann, I., Kummer, B., Niedlich, S., \& Rieckmann, M. (2018). Sustainability Governance at Universities: Using a Governance Equalizer as a Research Heuristic. Higher Education Policy, 31(4), 491-511.

Biermann, F., Abbott, K., Andresen, S., Bäckstrand, K., Bernstein, S., Betsill, M. M. et al. (2012). Navigating the Anthropocene: improving earth system governance. Science, 335(6074), 1306-1307.

Byrne, E., Desha, C., Fitzpatrick, J, \& Hargroves, K. (2010). EESD: A review of international progress. Workshop paper for 3rd International Symposium for Engineering Education. Cork, 30 June - 2 July 2010 .

Ceulemans, K., Molderez, I., \& Van Liedekerke, L. (2015). Sustainability reporting in higher education: A comprehensive review of the recent literature and paths for further research. Journal of Cleaner Production, 106, 127-143.

Christensen, L. J., Peirce, E., Hartman, L. P., Hoffman, W. M., \& Carrier, J. (2007). Ethics, CSR, and sustainability education in the Financial Times top 50 global business schools: Baseline data and future research directions. Journal of Business Ethics, 73(4), 347-368.

Cobián, R. A., \& Reátegui, F. (2009). Toward systemic social transformation: Truth commissions and development. Transitional justice and development: Making connections, 158-159.

Connolly, T. M., Stansfield, M., \& Hainey, T. (2007). An application of games-based learning within software engineering. British Journal of Educational Technology, 38(3), 416-428.

Coutinho, V., Domingues, A. R., Caeiro, S., Painho, M., Antunes, P., Santos, R., Videira, N.; Huisingh, D. \& Ramos, T. B. (2018). Employee-Driven Sustainability Performance Assessment in Public Organisations. Corporate Social Responsibility and Environmental Management, 25(1), 29-46.

Crow, M. M. (2010a). Organizing teaching and research to address the grand challenges of sustainable development. BioScience, 60(7), 488-489.

Crow, M. M. (2010b). Toward Institutional Innovation in America's Colleges and Universities. Trusteeship, 18(3), 8-13.

Dacin, M. T., Dacin, P. A., \& Tracey, P. (2011). Social entrepreneurship: A critique and future directions. Organization science, 22(5), 1203-1213.

Deemer, R., \& Horvath, V. (2017). Shared Governance from Both Sides of the Fence. Shared Governance in Higher Education, Volume 2: New Paradigms, Evolving Perspectives, 2, 21.

Disterheft, A., Caeiro, S. S., Leal Filho, W., \& Azeiteiro, U. M. (2016). The INDICARE-modelmeasuring and caring about participation in higher education's sustainability assessment. Ecological Indicators, 63, 172-186. 
Disterheft, A., Caeiro, S., Azeiteiro, U., Filho, W., \& Leal Filho, W. (2015). Sustainable universities a study of critical success factors for participatory approaches. Journal of Cleaner Production, 106, 1121.

Drahein, A. D., De Lima, E. P., \& Da Costa, S. E. G. (2019). Sustainability assessment of the service operations at seven higher education institutions in Brazil. Journal of Cleaner Production, 212, 527536.

European Union (2018). Summaries of EU Legislation. Glossary of summaries, https://eurlex.europa.eu/summary/glossary/governance.html Accessed 28 February 2019.

Ferrero-Ferrero, I., Fernández-Izquierdo, M. Á., Muñoz-Torres, M. J., \& Bellés-Colomer, L. (2018). Stakeholder engagement in sustainability reporting in higher education: An analysis of key internal stakeholders' expectations. International Journal of Sustainability in Higher Education, 19(2), 313-336.

Findler, F., Schönherr, N., Lozano, R., \& Stacherl, B. (2019). Assessing the impacts of higher education institutions on sustainable Development - An analysis of tools and indicators. Sustainability, https://doi.org/10.3390/su11010059.

Fonseca, A., Macdonald, A., Dandy, E., \& Valenti, P. (2011). The state of sustainability reporting at canadian universities. International Journal of Sustainability in Higher Education, 12(1), 22-40.

Gamage, P., \& Sciulli, N. (2017). Sustainability reporting by Australian universities. Australian Journal of Public Administration, 76(2), 187-203.

Gibbons, M. (1999). Science's new social contract with society. Nature, 402(6761supp), C81.

Global Reporting Initiative (2013). G4 Sustainability Reporting Guidelines. Reporting principles and standard disclosures, Global Reporting Initiative. https://www.globalreporting.org/resourcelibrary/GRIG4-Part1-Reporting-Principles-and-StandardDisclosures.pdf Accessed 17 May 2019.

HESI (2017). Higher education institutions - key drivers of the sustainable development goals. A special event of the 2017 High-level Political Forum on Sustainable Development, UN HQ, New York, NY.

Johnson, L., Becker, S. A., Cummins, M., Estrada, V., Freeman, A., \& Hall, C. (2016). NMC horizon report: 2016 higher education edition (pp. 1-50). The New Media Consortium.

Jones, G. R. (2013). Organizational theory, design, and change. Harlow, UK: Pearson Education Limited.

Jones, P., Selby, D., \& Sterling, S. (2010). Introduction. In P. Jones, D Selby \& S Sterling (Eds.), Sustainability Education: Perspectives and Practice Across Higher Education. Earthscan: London.

Keddy, P. A. (1991). Working with heterogeneity: an operator's guide to environmental gradients. In Ecological heterogeneity (pp. 181-201). New York: Springer.

Klugman, J. (1999). Financing and governance of education in central Asia. MOST: Economic Policy in Transitional Economies, 9(4), 423-442.

Kjaer, A. (2011). Rhodes' contribution to governance theory: Praise, criticism and the future governance debate. Public Administration, 89(1), 101-113. 
Leal Filho, W. (2010). Teaching sustainable development at university level: current trends and future needs. Journal of Baltic Science Education, 9(4), 273-284.

Leal Filho, W. (ed.) (2012) Sustainable Development at Universities, Frankfurt: Peter Lang.

Leal Filho, W., Pallant, E., Enete, A., Richter, B., \& Brandli, L. L. (2018). Planning and implementing sustainability in higher education institutions: an overview of the difficulties and potentials. International Journal of Sustainable Development \& World Ecology, 25(8), 713-721.

Leal Filho, W., Brandli, L. L., Becker, D., Skanavis, C., Kounani, A., Sardi, C. et al. Sustainable development policies as indicators and pre-conditions for sustainability efforts at universities: Fact or fiction? International Journal of Sustainability in Higher Education, 19(1), 85-113.

Leer, R., \& Ivanov, S. (2013). Rethinking the future of learning: the possibilities and limitations of technology in education in the 21st century. International Journal of Organizational Innovation (Online), 5(4), 14.

Lozano, R. (2006). Tool for a graphical assessment of sustainability in universities (GASU). Journal of Cleaner Production, 14(9-11), 963-972.

Lozano, R. (2011). The state of sustainability reporting in universities. International Journal of Sustainability in Higher Education, 12(1), 67-78.

Lozano, R. (2018). Sustainable business models: Providing a more holistic perspective. Business Strategy and the Environment, 27(8), 1159-1166.

Lozano, R., Ceulemans, K., Alonso-Almeida, M., Huisingh, D., Lozano, F. J., Waas, T., Lambrechts, W.; Lukmanjk, R. \& Hugé, J. (2015). A review of commitment and implementation of sustainable development in higher education: results from a worldwide survey. Journal of Cleaner Production, 108, $1-18$.

Mader, C., Scott G., \& Dzulkifli, A.R. (2013). Effective change management, governance and policy for sustainability transformation in higher education. Sustainability 4(3), 264-284.

Nanda, V. (2006). The "Good governance" concept revisited. The Annals of the American Academy of Political and Social Science, 603(1), 269-283.

Nordqvist, M., Sharma, P., \& Chirico, F. (2014). Family firm heterogeneity and governance: A configuration approach. Journal of Small Business Management, 52(2), 192-209.

Popescu, M., \& Beleau, C. (2014). Improving management of sustainable development in universities. Bulletin of the Transilvania University of Brasov, 7(56), 97-106.

Ramos, T. B., Caeiro, S., Van Hoof, B., Lozano, R., Huisingh, D., \& Ceulemans, K. (2015). Experiences from the implementation of sustainable development in higher education institutions: Environmental management for sustainable universities. Journal of Cleaner Production, 106, 3-10.

Rath, K., \& Schmitt, C. T. (2017). Sustainability at universities: Degrees of institutionalization for sustainability at German higher education institutions - A categorization pattern. Handbook of theory and practice of sustainable development in higher education (pp. 451-470) Springer.

Rosenau, J. N. (2009). Governance in the twenty-first century. In Palgrave Advances in Global Governance (pp. 7-40). London: Palgrave Macmillan. 
Schmidt, J. J., \& Peppard, C. Z. (2014). Water ethics on a human-dominated planet: rationality, context and values in global governance. Wiley Interdisciplinary Reviews: Water, 1(6), 533-547.

Shephard, K. (2008). Higher education for sustainability: seeking affective learning outcomes. International journal of sustainability in Higher Education, 9(1), 87-98.

Smith, A. A. (1993). Campus Ecology: a Guide to Assessing Environmental Quality and Creating Strategies for Change. Living Planet, Los Angeles.

Sivapalan, S. (2016). Engineering Education for Sustainable Development in Malaysia: Student Stakeholders Perspectives on the Integration of Holistic Sustainability Competences Within Undergraduate Engineering Programmes. In: Leal Filho W., Brandli L. (eds) Engaging Stakeholders in Education for Sustainable Development at University Level. World Sustainability Series. Springer: Cham.

Soini, K., Jurgilevich, A., Pietikäinen, J., \& Korhonen-Kurki, K. (2018). Universities responding to the call for sustainability: A typology of sustainability centres. Journal of Cleaner Production, 170, 14231432.

Spira, F., Tappeser, V., \& Meyer, A. (2013). Perspectives on sustainability governance from universities in the USA, UK, and Germany: how do change agents employ different tools to alter organizational cultures and structures?. In: Sustainability Assessment Tools in Higher Education Institutions (pp. 175187). Springer, Cham. https://doi.org/10.1007/978-3-319-02375-5 10.

Stiglitz, J. E. (1999). The World Bank at the millennium. The Economic Journal, 109(459), F597. https://doi.org/10.1111/1468-0297.00473.

Tappeser, V. \& Mayer, A. (2012). Change-Agents in Sustainability Governance: Institutional Transformation at Three Institutions of Higher Education. In: Leal Filho, W. (ed) Sustainable Development at Universities: New Horizons. Peter Lang Scientific Publishers: Frankfurt.

Trencher, G., Bai, X., Evans, J., McCormick, K., \& Yarime, M. (2014). University partnerships for codesigning and co-producing urban sustainability. Global Environmental Change, 28, 153-165.

U.S. AID. (2005). Policy. Nine principles of development and reconstruction assistance. www.usaid.gov/policy Accessed 27 February 2019.

UN (United Nations) (1972). Report of the United Nations on the human environment. Stockholm, 516 June 1972. A/CONF.48/14/Rev.1. http:/www.un-documents.net/aconf48-14r1.pdf and http://www.un-documents.net/unchedec.htm Accessed 3 March 2019.

UN (United Nations) (2019). Higher Education Sustainability Initiative (HESI). https://sustainabledevelopment.un.org/sdinaction/hesi Accessed 03 March 2019.

van Zeijl-Rozema, A., Cörvers, R., Kemp, R., and Martens, P. (2008). Governance for sustainable development: a framework, Sustainable Development, 16 (6), pp. 410-421.

Vaughter, P., McKenzie, M., Lidstone, L. \& Wright, T. (2016). Campus sustainability governance in Canada: A content analysis of post-secondary institutions' sustainability policies. International Journal of Sustainability in Higher Education, 17 (1), pp.16-39.

Vorley, T., \& Nelles, J. (2009). Building entrepreneurial architectures: A conceptual interpretation of the third mission. Policy Futures in Education, 7(3), 284-296. 
Wals, A. E. J., Tassone, V. C., Hampson, G. P., \& Reams, J. (2016). Learning for walking the change: eco-social innovation through sustainability-oriented higher education, in M. Barth, G. Michelsen, I. Thomas, and M. Rieckmann (eds.) Routledge Handbook of Higher Education for Sustainable Development, London: Routledge, pp. 25-39.

WCED. (1987). Our common future. Oxford, UK: Oxford University Press.

World Bank. 1992. Governance and development (English). Washington, DC: The World Bank. http://documents.worldbank.org/curated/en/604951468739447676/Governance-and-development Accessed 28 February 2019.

Yee, N. (2006). The Demographics, Motivations and Derived Experiences of Users of MassivelyMultiuser Online Graphical Environments. PRESENCE: Teleoperators and Virtual Environments, 15, 309-329. 